\title{
Riding the subscription box wave: Understanding the landscape, challenges, and critical success factors of the subscription box industry
}

\author{
Yana Andonova \\ Murray State University, yandonova@murraystate.edu \\ Nwamaka A. Anaza \\ Southern Illinois University Carbondale \\ Delancy H.S. Bennett \\ Clemson University
}

Follow this and additional works at: https://digitalcommons.murraystate.edu/faculty

Part of the Business Commons

(c) $($ ) $(9)$

This work is licensed under a Creative Commons Attribution-NonCommercial-No Derivative Works 4.0 International License.

\section{Recommended Citation}

Andonova, Y., Anaza, N. A., \& Bennett, D. H. (2021). Riding the subscription box wave: Understanding the landscape, challenges, and critical success factors of the subscription box industry. Business Horizons. https://doi.org/10.1016/j.bushor.2021.02.024

This Journal Article is brought to you for free and open access by the Faculty Works at Murray State's Digital Commons. It has been accepted for inclusion in Faculty \& Staff Research and Creative Activity by an authorized administrator of Murray State's Digital Commons. For more information, please contact msu.digitalcommons@murraystate.edu. 
Riding the subscription box wave: Understanding the landscape, challenges, and critical success factors of the subscription box industry

Dr. Yana Andonova*

(PhD University of Massachusetts)

Assistant Professor of Marketing

Arthur J. Bauernfeind College of Business, Murray State University

413E Business Building

Murray, Kentucky 42071

(p) 270-809-4766

(f) 270-809-3482

yandonova@murraystate.edu

Dr. Nwamaka A. Anaza

(PhD Purdue University)

Associate Professor of Marketing

Southern Illinois University Carbondale

Rehn Hall Rm 229, 1025 Lincoln Drive, Carbondale IL 62901

(p) 618-453-4341

(f) 618- 453- 7747

nanaza@siu.edu

Dr. Delancy H.S. Bennett

(PhD University of Massachusetts)

Assistant Professor of Marketing

Clemson University, College of Business

253 Sirrine Hall, Clemson University

Clemson SC, 29634

(p) 336-601-4751

(f) 864-656-8061

delancb@clemson.edu

*Corresponding author 
Riding the subscription box wave: Understanding the landscape, challenges, and critical success factors of the subscription box industry

\begin{abstract}
The subscription box e-commerce industry has experienced tremendous growth over the last five years. Given the growing size of the industry, this business model warrants direction for firms currently offering subscription services as well as companies considering entering this industry. This paper presents a detailed overview of the subscription box industry and proposes a framework for understanding subscription offerings (the 4 C's). Second, it identifies challenges and opportunities facing this industry. Lastly, it provides managers with guidance in the form of five tenets on how to navigate the subscription box economy.
\end{abstract}

Keywords: subscription services, subscription boxes, subscription e-commerce, meal kits, beauty boxes 


\section{The Rise of Subscription Boxes}

Subscription boxes, the purchase of a monthly set of often customizable or surprising items that are mailed to the end user, have exploded in the marketplace, growing at an annual but steady rate of more than 100\% over the last five years (Chen, Fenyo, Yang, \& Zhang, 2018). This growth rate has further accelerated in 2020 due to the coronavirus pandemic (Koetsier, 2020; Seetharaman, 2020). Initiated by start-up companies like Birchbox, Ipsy, and the Dollar Shave Club, subscriptions accounted for approximately \$15B in U.S. sales in 2018 (Chang, 2019). Further, it has been projected that $75 \%$ of organizations selling directly to consumers will offer subscription services by 2023 (Gartner, 2019). Not surprising, industry giants like Amazon (Amazon Subscribe \& Save), P\&G (Venus Club), and Walmart (Beauty Box) have adopted this business model to capitalize on this multi-billion-dollar industry. Still several startups and other well-known brands like Gap, Under Armour and Adidas have failed with their subscription box service (SBS) offerings. More recently, Sephora announced it was discontinuing its beauty box (Simeon, 2020).

Given the number of firms moving to leverage this model and the number of failed subscription services from well-known companies, it is clear that managers need guidance on how to successfully navigate the SBS landscape. However, both the academic and practitioner literature has paid limited attention to subscription services (e.g., Bischof et al., 2020; Rudolph et al., 2017; Sivathanu, 2018; Noorda, 2019). Therefore, the purpose of this article is to assist managers who wish to navigate this industry. In doing so, we first provide a detailed overview of the SBS landscape via the four C's of subscription boxes, a framework we propose as a useful tool for understanding SBS. Second, we identify opportunities within several product categories and discuss customer churn, a key challenge that managers in this industry face. Last, we offer 
five tenets to help practitioners overcome customer churn and succeed in the subscription economy.

\section{The 4 C's of SBS: Categories, Consumer Benefits, Customers, and Competitive}

\section{Landscape}

What makes the SBS business model incredibly attractive to firms is the potential steady revenue stream from subscribers. Subscription boxes reduce consumer decision-making efforts associated with the countless options and choices in brick-and-mortar stores (Bischof et al., 2020). Unlike membership-based models where individuals pay to become members of the business in order to obtain or use the services provided (e.g. gym memberships, internet service), SBS consumers are not members of any business, but instead are subscribers to services, which allow them direct access to boxed-based offerings (Bischof et al., 2020). Given the absence of a locked-in, membership-based model, SBS consumers are not bound to long-term contracts unless they choose an annual vs. a monthly subscription, but rather are free to come and go as they please. However, a disadvantage is that some consumers may be wary of signing up as they are enrolling in a recurrent billing system (Chen et al., 2018). An even bigger disadvantage is the high churn rate as most of these services allow cancellations at any time. In fact, on average nearly $40 \%$ of subscribers have cancelled their subscriptions (Chen et al., 2018).

Given that the cost of acquiring a new customer is higher than retaining an existing one (Panko, 2019), companies currently offering or planning to offer subscription services in the future need to understand this dynamic industry. This paper proposes a framework for understanding the subscription box industry that builds upon core marketing elements. We refer to the framework as the 4C's of SBS: Categories, Consumer Benefits, Customers, and 
Competitive Landscape (Figure 1). This 4C's framework is grounded in existing marketing literature regarding successful elements of subscription strategies. More specifically, we build on past investigations on subscriber characteristics (Woo \& Ramkumar, 2018), subscriber motivations (Chen et al., 2018), subscription types (Bischof et. al., 2020) and subscription competition (Rudolph et al., 2017). These four elements create a foundation for understanding the subscription box industry. For example, several studies (e.g., Bischof et al., 2020; Rudolph et al., 2017) have identified and legitimized the need to understand subscription box categorization (categories) from a strategic perspective as each category holds a different value proposition. Further, Bischof et al. (2020) argued that different types of subscriptions, (e.g. predefined and curated) involve different degrees of perceived risk and thus require different marketing strategies. Rudolph et al. (2017) categorized subscriptions based on the degree of surprise involved which refers to the extent to which consumers can control the content of their boxes. Finally, Chen et al. (2018) focused on personalization and subscribers' motivations.

Researchers contend that SBS are primarily popular among millennials (Chen et al., 2018). Studies on the characteristics that distinguish subscribers from non-subscribers have found that e-tailer trust and fashion consciousness predict the adoption of subscription services for beauty and apparel subscriptions, but age does not (Woo \& Ramkumar, 2018). In contrast, benefits that motivate customers to use subscription services have been highlighted as a core component for the subscription industry (Chen et al., 2018) and therefore are included in this framework. Holistic evaluation of the subscription industry would be incomplete without examining the competitive landscape (Rudolph et al., 2017). Every sustainable subscription business model must consider competition especially in the era of sharing economies (Curtis \& Mont, 2020). SBS are growing in the market, some competing on convenience and others on 
price or even both (Chen et al., 2018; The Consumer Subscription Services Report, 2020). But to survive in a potentially hyper-competitive market, competitors must demonstrate an unduplicable sustainable edge over other competitors (Henderson, 1983). With over 7000 subscription boxes in global markets, managers must understand the nuances of this crowded competitive landscape (Horstmeyer, 2020). Given these different elements, we develop a baseline framework for understanding and integrating these important aspects of SBS. Next, we discuss each of these components in more detail.

[Insert Figure 1 about here]

\subsection{Categories}

The establishment of industry categories is important for firms and consumers (Rosa \& Porac, 2002). From a managerial standpoint, categorization allows for the classification of offerings to different consumer groups and provides for an understanding of the opportunities for positioning and branding. For example, establishing categorization is necessary for designing and pricing products per consumer expectations as well as for differentiating the product from other category members (Viswanathan \& Childers, 1999). For consumers, categorization has been suggested to both precede and influence product evaluation (Viswanathan \& Childers, 1999) and, therefore, purchase. To date, listings of categories within the SBS industry are limited. A few industry reports (i.e., SUBTA, 2019 and Hitwise, 2018) have identified a small number of SBS categories (e.g., beauty/grooming, food, apparel, etc.). However, these reports tend to focus on a single product attribute-based categorization (i.e. food) that is limited to the topic of their research and too broad to offer detailed understanding and exemplars. Thus, a comprehensive categorization has yet to be developed. To this end, we synthesized and compiled the current listings to offer a more complete categorization. In doing so, we expand beyond the limitations of single-attribute 
listings, which tend to be too general for strategic use, to include categorization based on usage and benefits (see Rosa \& Porac, 2002) as well as market size.

This approach resulted in the deconstruction of some previously defined categories. For example, although beauty and grooming are related, we separate the two here as the SBS beauty category is based on allowing consumers to try new products while SBS grooming products (which we list as personal care) are more about convenience and cost-saving benefits (Chen et al., 2018). Likewise, meal kits should be regarded as a separate category from food due to their market size — a \$1.7B market in the U.S. alone (Statista, 2019). In addition, unlike ready-to-eat snacks or other offerings categorized as food, meal kits provide an opportunity for customer cocreation in the form of following the enclosed recipes, the benefits of which may be simultaneously utilitarian (making a meal or learning to cook) and also hedonic (a fun bonding experience with family or friends). Thus, a more nuanced categorization for the SBS industry is offered, one that details each category and identifies exemplars and opportunities for growth within each. Table 1 presents an overview of some of the most popular types of SBS and key players in each category.

[Insert Table 1 about here]

Beauty boxes were among the first types of SBS to enter the market. Some of the main motivations for subscribing to beauty boxes include discovering new products and receiving high quality products at a reasonable price (Statista, 2017). They appeal to consumers due to the element of surprise and the opportunity to sample an expensive product without having to purchase the full size, thus reducing the financial risk associated with potentially not liking an expensive product. According to a report by hitwise (2018), beauty boxes experienced a $1 \%$ 
decline in 2018 from the year before, which indicates this category has likely entered the maturity stage of the product life cycle. However, opportunities may be found in premium markets. According to a recent Global Cosmetic Industry Report (Gleason-Allured, 2018), the prestige skincare sector has experienced an accelerated growth since 2017 , driven by various trends including K-beauty (Korean beauty), indie brands, innovation, and product customization. Leading companies in the beauty SBS market include Ipsy, Birchbox, and Allure.

Personal care boxes, razors in particular, appeal to consumers due to savings and convenience (having items delivered to your doorstep before you run out). The first entrant in this highly competitive SBS category was the Dollar Shave Club, whose success has attracted many competitors such as Harry’s, Billie, and Flamingo. Hair color subscriptions such as Madison Reed have thrived during the coronavirus pandemic, attracting consumers unable to go to hair salons due to closures, yet looking for a more personalized experience (Saltzman, 2020).

Meal kit subscriptions have become a popular subscription service, albeit one that has a high cancellation rate. In fact, meal kit subscriptions have among the highest cancellation among SBS. The meal kits market in the U.S. alone is \$1.7B (Statista, 2019) or roughly half of the $\$ 3.46 \mathrm{~B}$ meal kits market worldwide. Currently only about $3 \%$ of Americans are subscribed to a meal kit service representing a huge market opportunity (Kneen, 2018). Meal kits are particularly popular with millennial males and families with kids that earn $\$ 70,000$ or above (Nielsen, 2017). Meal kits save time on various tasks including grocery shopping, food prepping, and planning. For those consumers who are inexperienced when it comes to cooking, meal kits may also help with learning to cook as they provide detailed recipe instructions. Where meal kits fall short is that some consumers are getting mindful of the effect of packaging on the environment (e.g. cardboard, plastics, and freeze packs that come with each kit). As previously mentioned, 
retention rate is a concern for meal kit companies. Hello Fresh, a popular choice, reports only $11 \%$ retention (Statista, 2017). Leading companies in the market are Blue Apron, HelloFresh, and Daily Harvest (See Table 1 for other players in the market).

Food and beverage subscriptions include snacks, produce, alcohol (e.g., wine, craft beer, cocktails) and non-alcohol drinks (e.g., artisan tea, coffee). These are niche products and typically attract consumers looking for premium (e.g. hand-crafted, pure, organic, loose leaf tea, coffee beans from sustainable farms, etc.) or unique gifts. According to Ramasamy (2018), food and beverages boxes grew at a compound annual growth rate of $146.5 \%$ in 2018 . Popular examples include Wine of the Month Club, Tasting Room (wine), Misfits Markets (produce), and Graze (healthy snacks).

Apparel boxes is another popular category as evidenced by the growth in online visits for such services_-visits grew 11\% in 2019 (SUBTA, 2019). Some of these boxes allow consumers to set a budget as to how much they want to spend (e.g. Stitch Fix, Nordstrom's Trunk Club) while others offer clothing rental and unlimited box swaps each month (e.g. Infinite Style by Ann Taylor). These services are typically offered at a premium price and target a niche market. For example, they offer a seemingly limitless wardrobe to the modern businesswoman who is too busy to shop for herself and could possibly deliver savings opportunities as well (e.g. clothes purchased for a specific occasion and only worn once). While the majority of these boxes are targeting women, it should be noted that apparel boxes for men and kids can also be found on the market. Leading companies in the apparel SBS market include Fabletics, Stitch Fix, and Nordstrom Trunk Club.

Kids' subscription boxes as categorized here do not include clothes but rather refer to boxes that offer educational toys and crafts (e.g., KiwiCo, Little Passports). Online visits to 
websites offering kids' boxes grew only 2\% in 2019 (SUBTA, 2019). These boxes use a combination of demographic and psychographic segmentation as they segment by kids' age and interest. Average prices range from $\$ 15-\$ 30$ a month. Amazon has also entered this categoryits Amazon STEM Toy Club offers a selection of curated toys for science, technology, engineering, and math for kids of different age groups. Amazon Prime book box offers a choice of books (hardcover or board books) for different ages.

Pet supplies boxes have been gaining momentum during the coronavirus pandemic (Robert, 2020). These boxes feature toys, treats, and pet accessories. The total size of the pet food and treats market in the U.S. in 2019 was \$36.9B (Statista, 2020). This huge market clearly has not been unnoticed by innovative companies providing subscriptions targeting pet owners.

\subsection{Consumer benefits}

Product and service providers deliver value to consumers by providing goods that offer utilitarian and hedonic benefits (Carpenter \& Fairhurst, 2005). Different consumer benefits trigger interest in subscribing to boxes—ranging from utilitarian (e.g., the convenience of replacing items) to hedonic (e.g., the ability to try new products and the element of surprise) (Chen et al., 2018). Evidence of such benefits is displayed in the myriad of unboxing YouTube videos that both influencers and everyday consumers have been eager to share. After reviewing the literature on SBS, we identified nine types of benefits that subscription boxes offer consumers: replenishment, curation, surprise, access, affiliation, cost-based, discovery, educational, and lifestyle (see Table 2).

[Insert Table 2 about here] 
The typology provided here is based on summating the significant subscription box benefits as outlined in the current literature. For example, Rudolph et al. (2017) identified "predefined subscriptions that ship commoditized items" (replenishment), "curated subscriptions that ship products of a certain category selected in accordance with consumers' preferences" (curation), and "subscriptions that ship boxes with content that cannot be controlled by consumers," (surprise) (p. 21). Further, Chen et al. (2018) add members-only benefits such as lower prices and boxes that provide exclusive products (access). A detailed description of each of the nine types of benefits, literature sources, and category exemplars is provided in Table 2.

\subsection{Customers: Understanding subscription box customers}

Although SBS have seen steady growth, only $15 \%$ of online consumers said they subscribed to a subscription service in 2018 (Chen et al., 2018). The majority of these subscribers tend to be young women living in urban areas. Women account for $60 \%$ of total subscriptions. However,

men tend to have a higher number of subscriptions per person than women (Chen et al., 2018). In fact, $42 \%$ of men (compared to $28 \%$ of women) reported having on average three subscriptions (Chen et al., 2018). In addition, subscribers tend to have high incomes, with approximately 54\% reporting incomes over \$100,000 (The Consumer Subscription Services Report, 2020).

Subscription boxes are primarily popular with millennials: $13.8 \%$ of millennials have subscriptions followed by $10.4 \%$ of Generation Z, $9.5 \%$ of Gen X, and 3.7\% of Baby Boomers (The Consumer Subscription Services Report, 2020).

A study by Woo and Ramkumar (2018) found that age was not a factor in predicting adoption of SBS for beauty and apparel. This finding suggests that there may be an opportunity to pursue segments such as Generation $\mathrm{X}$ and Baby Boomers more effectively by targeting them with product categories they find relevant. Generation X may present a challenge as they are not 
prone to extravagance (Kerin \& Hartley, 2019). However, these consumers invest in home improvement projects (Carlyle, 2019). Therefore, subscription boxes related to home decor might be particularly appealing to them. Given that Generation X consumers tend to be more practical, they may want control over the items in their subscription boxes, suggesting that customization could be key to targeting them effectively. As Baby Boomers age, potential product categories that may appeal to them include health supplements and anti-aging products. Given that Baby Boomers are the wealthiest generation and account for approximately $50 \%$ of all consumer spending (Kerin \& Hartley, 2019), efforts should be placed into acquiring them as subscribers.

Since Generation Z consumers were born after 1997 (Pew Research Center, 2019), most have not yet become economic adults and, thus, have limited discretionary incomes. However, as previously stated, they are only slightly behind millennials in adopting the subscription box lifestyle (The Consumer Subscription Services Report, 2020), suggesting that once they become financially independent, they will likely surpass millennials as the largest consumer group in the subscription box marketplace.

\subsection{Competitive landscape}

With more than 7,000 subscription box services in a highly competitive marketspace (Horstmeyer, 2020), the question of how providers of similar product categories can distinguish themselves remains particularly pertinent, but sadly unanswered. The competitive nature of this industry is compounded by the difficulty in distinguishing among similar services in the same product category. For example, consumers in search of a healthy meal kit subscription can find a host of service providers (e.g., HelloFresh, Blue Apron, Home Chef, among others), all offering similar produce selections, food quality (organic vs. non-GMO), shipping policies (e.g., free 
shipping), ingredients, cancellation plans, meal options (plant-based vs. meat-based), recipe options (20 recipes vs. 50 recipes) and size options (meal for 2 vs. 4; bigger vs. smaller vs. sample boxes). The substantial similarities between products coupled with high-price competition in a commitment-free environment (consumers determining their own cancellation plans vs. contract-free options) influence the elasticity of demand. This situation indicates that the homogeneity within subscription box product categories challenges the notion that subscription e-commerce providers can indeed stand out, raising important questions concerning the ability and viability of firms to gain a lasting competitive advantage in the SBS industry (Petro, 2019).

High levels of competition lead to concerns about consumer saturation. While the subscription box industry is not yet saturated, the growing demand for such services along with the certainty of new entrants indicate future market saturation (Petro, 2019), which will only increase the fight for market share. With more subscription services likely flooding the market over the next few years, predicting consumer and market saturation points will help firms at the introductory, growth, and maturity phases of the service life cycle effectively manage marketing costs and profit maximization. Moreover, managers must question the extent to which consumers may begin to feel overwhelmed by the services themselves and the communication from these service providers. In an era where minimalism and simplicity are gaining popularity (as seen with the tiny house movement and "Tidying up with Marie Condo"), determining consumers' diminishing marginal utility across different product categories and demographic groups will likely explain how and if customers will continue to see value in these services over time. Thus, while consumers may initially be interested in various new products, the mix of products, 
product personalization, and the element of surprise, at what point do they say enough is enough or, in this case, how many boxes are too many?

Competition in the subscription box service industry is giving way to mergers, acquisitions, and possible coopetition. For example, in 2012, Birchbox acquired JolieBox (Chabbra, 2015). Unilever acquired the U.S.-based Dollar Shave Club in 2016 for $\$ 1$ billion, the largest acquisition in the SBS industry to date, and in 2019, Unilever also acquired Graze the British-based snack food box company for a reported $£ 150 \mathrm{~m}$ (The Paypers, 2019). The acquisition of Plated by Albertson in 2017, Home Chef by Kroger in 2018, and Walgreens's minority interest in Birchbox in 2018 (The Paypers, 2019) indicate that consolidations in the subscription box industry may serve as an avenue to curtail competition. However, no panel nor longitudinal studies are available to validate these assumptions. Neither are there studies exploring the processes, risks, and regulations of such integrations. Of particular interest must be the legal and ethical ramifications of such consolidations in economies that support marketplace competition such as the U.S. economy. For example, the Federal Trade Commission recently blocked a $\$ 1.4$ billion acquisition of Harry's, a shaving subscription box service, by Edgewell Personal Care on the grounds that this consolidation would stifle competition and increase consumer prices (Fickenscher, 2020). This situation raises important questions concerning governmental apprehension over consolidations involving SBS. As such, not only should managers be interested in questions involving the successful execution of integration plans, but they should also be vested in understanding the regulatory and ethical considerations often overlooked in relation to mergers and acquisitions. 


\section{Customer Churn-A Major Challenge}

SBS provide more than goods; they also provide an experience, and consumers are quick to cancel if they are not satisfied (Chen et al., 2018). In fact, on average $40 \%$ of subscribers have cancelled a subscription service (Chen et al., 2018), with churn rates varying across product categories, from the lowest for beauty and apparel at approximately $10 \%$ for both categories (SUBTA, 2019) to the highest for meal kit companies at 60 to $70 \%$ (Chen et al., 2018).

Moreover, the average subscriber to a meal kit service remains subscribed for only a week (Statista, 2017), implying that most are simply trying out the service or taking advantage of a promotional introductory offer. Furthermore, only $9 \%$ of meal kit subscribers have kept their subscriptions for more than six months (Statista, 2017), suggesting that these companies are making their profits primarily from new subscribers as opposed to cultivating loyal consumers, a situation signaling a major problem in the industry. Two of the leading motivations for unsubscribing are the expense of the boxes and consumers' becoming dissatisfied with the variety of products they received (Statista, 2017). Other reasons why the churn rate is high for subscription boxes include an overall ineffective marketing strategy that ignores consumer needs and preferences. To further explore the issue of churn and the four C's framework, we analyze both within the context of an actual firm—-beauty product supplier Birchbox.

\section{Case study: Birchbox}

Founded in 2010 by two Harvard graduates, Hayley Barna and Katia Beauchamp, Birchbox pioneered the SBS industry and quickly became a household name. At a relatively affordable monthly price of $\$ 10$ (which increased to $\$ 15$ in 2019), Birchbox provided consumers the opportunity to sample beauty products. In terms of the Four C's, Birchbox operated in the beauty category and provided consumers curated products. Initially the company's core customer was 
the woman who felt overwhelmed by the multitude of options available at department stores, but by 2012, Birchbox launched their men's subscription box. Birchbox's co-founder was quoted as saying that the company found a new type of consumer, one that other firms were ignoring, and as a result the company is "actually competing with non-consumption" (Robischon, 2015). However, once Birchbox became popular, many companies jumped on this easy-to-copy business model (Torres, 2019). The presence of copycat boxes contributed to customer churn. Sadly, Birchbox struggled to adapt to consumers' evolving demands and was unable to secure its position as distinctively valuable to consumers (something Ipsy, its competitor, quickly learned to do).

Birchbox struggled to stay profitable. Churn rate within its first three years of operation was around 10\% (Bloom, 2017). In 2016, the company laid off 25 percent of its workforce, stopped expansion plans to open more retail stores, and eliminated half of their human touchpoints for the personalization of products without replacing them with any technical support (Henry, 2020). Moreover, in the era of YouTube beauty influencers and online skincare tutorials from everyday women sharing inspirational stories that showed consumers different products and how to use them, Birchbox was slow to see value in such communication approaches, something its competitor Ipsy perfected that helped them get ahead (Segran, 2018). Ipsy along with Sephora's subscription Play! (now discontinued) were formidable early competitors that forced Birchbox to scale back its expansion. In fact, Birchbox completely stopped spending on marketing except social media and public relations and reduced its cost of assembling a beauty box (Henry, 2020).

Its business model at the time was inherently warped. Birchbox delivered boxes of customized, sample-sized beauty products to customers for free with the hope that customers 
would eventually buy full-size products. The problem was that Birchbox failed to incentivize these users to purchase full-size products from them given that the same beauty products could be purchased elsewhere at lower prices (Kosoff, 2016). Birchbox also faced repeated criticism from subscribers because the product samples they received often were unreflective of their personalized profiles (information users provided to tailor their beauty products to their preferences). In fact, many consumers complained that upon receiving their boxes, they were disappointed to find products that did not match their profiles and expectations (Leavitt, 2018). These consumer issues were compounded by limited venture investments to help the company scale its business (Kosoff, 2016). Today, Birchbox boasts of over a million subscribers and 2.5 million consumers across 6 nations with an annual revenue of \$200 million (Chen, 2019; Henry, 2020). The company sold Birchbox France and again laid out plans to lay off $25 \%$ of its global workforce (Weissman, 2020). While the company struggles to sustain profitability and subscription rates, they have, however, updated their social media strategy by using both staffers and influencers to create interactive live content such as behind-the-scenes videos to stay connected to subscribers. (YPulse, 2017).

\section{On the way to a strategy for managing SBS}

The Birchbox case study highlights the importance of social media influencers as a viable strategy for promoting subscription offerings. Along these lines, scholars have found that the impact of social media influencers on consumer brand awareness is particularly profound among millennials (Dhanesh \& Duthler, 2019). Given the prominence of subscriptions among millennial shoppers, it is worthwhile for SBS firms to consider harnessing the power of social media influencers. 
While influencers can increase consumer awareness about subscription offerings, interested consumers may still be reluctant to sign up for a subscription due to being wary of enrolling in automatic transactions (e.g., monthly billing). Thus, companies need to minimize the risk associated with trying subscription boxes. This could be achieved by making their goods available for one time purchases at distributors or by offering bricks and clicks. The ability to see an offering at a physical store gives consumers the opportunity to try out a product or service without the risk of subscribing. This is important as trial is a key step to product adoption and a critical factor to move an offering from the introductory phase of its product life cycle to the growth stage.

The Birchbox case, along with the alarming churn rate across different categories, demonstrates the growing concern of subscriber retention. Consequently, SBS managers must be equipped with strategies to effectively manage subscriber relationships. Convenience is an important reason for subscribing to boxes (Chen et al., 2018). In other words, eliminating the need to go to a store creates value for consumers (Randall et al., 2016). Ensuring customers continue to see value in their subscription experience is also necessary for a company to cultivate subscriber loyalty. But how exactly can subscription box firms cultivate loyalty in order to successfully manage their services? The following section provides answers to this question by elaborating more on five tenets for effectively managing subscription businesses.

\section{Five Tenets for Successfully Managing SBS}

We propose that endorsements via social media influencers, dual distribution (bricks and clicks), rewards programs, fostering and communicating perceptions of convenience, and value are 
reasons for subscribers to stay. The use of these tenets should aid in not only attracting new customers but also in retaining existing ones, thus minimizing customer churn.

\subsection{Leverage social media influencers}

Celebrity endorsers are individuals who leverage their public recognition to promote a product or service (McCracken, 1989). This categorization includes social media influencers who typically hold strong meaning and influence among their followers (Enke \& Borchers, 2019). As subscription boxes are heavily promoted to younger consumers and women in particular, the use of relatable social media influencers may prove to be more persuasive and cost-efficient than that of traditional celebrities. In addition, the content posted by influencers is often perceived as more candid than traditional ads (Campbell \& Farrell, 2020). In fact, beauty box Ipsy's Co-founder and CEO Marcelo Camberos was quoted as saying that "The Glam Bags were never the point ... these days, beauty brands don't decide what products are cool: Instead, it's beauty bloggers and other creators that are controlling the conversation ... we wanted to be at the forefront of the new way that consumers would interact with beauty brands (Sarabyn, 2017).” Therefore, we recommend that the subscription industry leverage social media influencers to promote continued patronage. Specifically, we propose creating the "Just for You" experience, which entails personalized encounters between subscribers and influencers and their social content. These encounters can be exciting live interactions with influencers that allow the brand to engage with subscribers after the purchase. For example, HelloFresh can co-develop recipes with a popular social media chef who performs a "free" live tutorial (or sends a video tutorial) and then offer curated boxes with these recipes to subscribers, thus creating a unique experience that is difficult to imitate. 


\subsection{Offer bricks and clicks}

It is important that subscription service providers partner with retail outlets to increase brand awareness and stimulate trials. Doing so allows for the leveraging of brick-and-mortar outlets as a form of distribution and a site for returning perishable goods. For example, Home Chef meals can be purchased at Kroger; HelloFresh, at Stop \& Shop; and Blue Apron at Costco. Madison Reed (a hair color subscription service) products are available at Ulta's stores and via Madison Reed hair salons in select cities. Bischof et al. (2020) found that the perceived risk of trying a new service negatively affected consumer attitude toward subscription offerings. However, in these examples, consumers have the opportunity to try out a product without subscribing and then decide if they wish to do so. Thus, a dual-distribution model where the consumer is able to purchase a box in-store in addition to online provides subscription box businesses with the possibility to capture a larger market size as well as decrease the perceived risk of subscribing. This approach may also help reduce churn as potential new subscribers would have had the opportunity to try out the service prior to subscribing and their decision to join would be based on a positive experience with their in-store box purchase.

Further, by offering brick and clicks, companies can also offer easy returns — customers dissatisfied with their boxes can drop them off at the store. In addition, while convenience is not the focus of this section, in-store box offerings allow for ordering online plus the convenience of same day pick-up in store. Thus, firms looking to establish themselves in this industry should look for outside partners and be willing to "go where the consumer already is" rather than take a "wait for the consumer to come to me" approach to build awareness, trial, and brand equity. This approach could also be expanded into the areas of cross-promotions or partnering with brick organizations where the two mutually benefit from promoting each other. 


\subsection{Reward customers for staying}

SBS companies should focus on providing a customized and highly desirable reward program to minimize subscriber churn and foster service continuity. Research in other areas of commerce has suggested that a healthy dose of ambiguity in the rewards program, rewards that are difficult to imitate (such as providing customers their own personalized boxes with items made just for them), and/or custom-made rewards (based on consumer preferences) could lead to enhanced emotional loyalty (Nastasoiu \& Vandenbosch, 2019). While many SBS companies like Birchbox utilize point-based reward systems, there are additional approaches managers should consider when focused on alleviating churn rate concerns. The following are reward programs that could curtail SBS churn for existing customers:

- A rewards program based on gamification principles, i.e., offering consumers discounted purchases from points gained by playing games.

- Free quarterly mini-boxes with surprise (unexpected) offerings based on customer preferences for product categories.

- Free quarterly mini-boxes personalized for the individual customer.

- Free returns for nonperishable boxed items within a time limit.

- Provide subscribers an ability to pause their subscription and continue at a later time.

\subsection{Increase perceptions of convenience}

Reducing churn rate requires subscription box providers to segment people based on their reasons for subscribing (Janzer, 2020), for example, those who subscribe for convenience. Subscription boxes offer convenience, which consumers are typically willing to pay more for (Bischof et al., 2020; Janzer, 2020). These services save time spent searching for products as well as time and energy on evaluating product alternatives and choosing among alternative 
options. Convenience is part of the SBS value proposition as there is value in eliminating the need and effort to go to a physical store (Randall et al., 2016). Meal kits, for example, provide convenience as they save time grocery shopping, meal planning, prepping, and even searching for recipes as all of those are included in the kit. As a result, meal kit subscriptions services charge a premium price over the cost of the ingredients needed to cook a particular meal. The key to increasing consumer perceptions of convenience is to constantly remind subscribers of the convenience of the service using compelling story-based messaging that focuses on the time, effort, decision, and transaction-based benefits enjoyed by actual users.

\subsection{Increase perceptions of value}

It is imperative that SBS firms increase subscribers' perceptions of value. While delivering value is important to all businesses, it is particularly paramount in SBS markets because of the high churn rate-consumers are quick to cancel a subscription when they no longer see value in it. Subscription cancellations are prominent in part because of the recurring monthly fees, making it an obvious choice when looking to cut down expenses especially when it comes to non-essential product categories. Thus, finding ways to signal to consumers that subscription boxes are valuable may hold one of the keys to subscriber retention. For example, when trying to assess the value of a box, consumers will try to identify the prices of each item and then total them. To determine the value, consumers often use price comparisons to similar products or services as reference points (Saint Clair et al., 2017). While this may be straightforward to do for certain offerings where prices can be easily found on the internet or even provided by the company itself to highlight the value of each box, it can be hard to do if the offerings are rare and unique. We suggest offering unique or hard to find items that, due to the difficulty of generating reference points, may increase the perceived value of the offering. For example, with meal kits, while one 
may have a reference point for how much it costs to get the necessary ingredients to make burgers and fries (i.e. a pound of ground beef, buns, ketchup, and a bag of fries), reference for the prices of unique items such as pickled onion jam spread, gourmet pretzel rolls, and ready-tofry BBQ with cheddar potato chips may be difficult to verify due to the uniqueness of the items. In such cases the cost, in terms of time, energy, and opportunity, for consumers to determine the value of the offering or to attempt to replicate its content via shopping in-store is too demanding. By offering unique and hard-to-find items that consumers cannot attach a price point to or have the patience to search for while shopping, the likelihood of substituting the offering with similar items decreases while its value proposition increases. Thus, leveraging uniqueness can be a highly successful tactic for not only attracting consumers but also for keeping them subscribed. Further, the uniqueness of the box assortment contributes to the overall subscription experience, making subscriptions a desired choice for an out-of-the-box gift idea.

Companies can also increase the perception of value by enabling box customization. While SBS consumers like to be surprised by the content of the boxes they receive (Bischof et al., 2020), allowing consumers to customize the content of their boxes to a certain degree will ensure that subscribers continue to see value in the overall subscription experience. For example, letting consumers choose what products they receive and what prices they pay for the box can help reduce churn as now subscribers are more in control of what they pay as opposed to a fixed amount determined by the provider. This could also strengthen the value proposition and provide differentiation among competitors.

Differentiation from their other offerings may also be necessary to increase the value of a subscription. When entering the SBS market, companies with existing in-store and online offerings must also differentiate their subscription service from what is already available for sale 
in these locations. For example, subscription boxes could feature limited product editions or early releases. By offering something different from what is currently available in any of their channels, a retailer will position its subscription as special and unique and will be able to offer something of value to the subscriber they cannot get elsewhere.

[Insert Figure 2 about here]

\section{Final Words}

With the explosion of subscription services, one may wonder if this trend is going to last over time. As consumers continue to value the convenience and variety that SBS offer, we believe that this business model will remain effective. However, due to the imminent future saturation of the U. S. subscription box marketplace, it is likely that the industry will begin consolidating, and many small players might leave the field as they find it difficult to compete. For this reason, it is critical for companies offering SBS to ensure that they are delivering a unique experience and to focus on the four C's of SBS and the five tenets for successfully managing these services as suggested in this paper. Like with any industry, both continuously monitoring the industry landscape and adapting to consumers' changing needs and expectations are key to being successful. Ensuring differentiation from competitors and allowing for personalization and customization are also important factors in reducing customer churn. Finally, expanding into foreign markets presents a significant opportunity for SBS companies as currently this business model is not as mainstream in other countries as it is in the U.S.

As with any new competitors, it is important for new entrants to either offer a product or service to a niche market or to be able to differentiate their services by providing consumers a sustainable advantage. Some of the SBS like beauty boxes currently appear to be saturated as 
evidenced by the decline in their growth rate. Other categories such as meal kits, apparel, and kids' boxes have been growing and, therefore, may be viable for those considering launching new SBS. For example, for meal kits, some niche categories may include meal kits for keto dieters and Asian or other international cuisine, to name a few. Nevertheless, it is easy for SBS to fail as illustrated by examples of apparel boxes no longer offered by Adidas, Under Armour, and Baby Gap. An understanding of the SBS landscape, its major challenges and tenets for success are offered here as an aid for managers and firms who wish to effectively compete in this arena. 


\section{REFERENCES}

Bischof, S. F., Boettger, T. M., \& Rudolph, T. (2020). Curated subscription commerce: A theoretical conceptualization. Journal of Retailing and Consumer Services, 54, 101822.

Bloom, S. (2017). Birchbox: the beauty of data. Available at: https://digital.hbs.edu/platformdigit/submission/birchbox-the-beauty-of-data/

Campbell, C., \& Farrell, J. R. (2020). More than meets the eye: The functional components underlying influencer marketing. Business Horizons, 63, 469-479.

Carlyle, E. (2020). Baby boomers and Gen Xers drove remodeling and spending in 2019.

https://www.houzz.com/magazine/baby-boomers-and-gen-xers-drove-remodeling-and-spendingin-2019-stsetivw-vs 137253690

Carpenter, J. M., \& Fairhurst, A. (2005). Consumer shopping value, satisfaction, and loyalty for retail apparel brands. Journal of Fashion Marketing and Management: An International Journal.

Chabbra, E (2015). Key to success: Beauty box company Birchbox says it's not just about the box. Forbes. Available at: https://www.forbes.com/sites/eshachhabra/2015/09/23/key-to-successbeauty-box-company-birchbox-says-its-not-just-about-the-box/\#6fe480036511

Chang, A. (2019). Subscription boxes may have lost the hype, but don't count them out just yet. Forbes. Available at_https://www.forbes.com/sites/andriacheng/2019/12/20/the-crowdedsubscription-box-industry-still-holds-growth-promise/\#403704e621 ae

Chen, T., Fenyo, K., Yang, S., and Zhang, J. (2018). Thinking inside the subscription box: New research on e-commerce consumers. McKinsey \& Co. Available at: https://www.mckinsey.com/industries/technology-media-and-telecommunications/ourinsights/thinking-inside-the-subscription-box-new-research-on-ecommerce-consumers.

Chen, C. (2019). Birchbox is raising its subscription price for the first time in 9 years - it's actually mostly good news for subscribers. Business Insider. Available at: https://www.businessinsider.com/birchbox-beauty-samples-newpricing\#: :text=Already\%20boasting\%20more\%20than\%201,a\%2Dprice\%20\%2410\%20monthl y\%20subscription.

Consumer Subscription Retail Services Report (April 2020). Available at https://www.pymnts.com/study/subscription-commerce-conversion-index-july-2020/ 
Cracknell, R. (2017). Sports Crate Subscription Box Launching with 10 MLB Teams. Available at https://www.beckett.com/news/sports-crate-subscription-service-launching-with-ten-mlbteams/

Curtis, S. K., \& Mont, O. (2020). Sharing economy business model for sustainability. Journal of Cleaner Production, 266, 1-15.

Dhanesh, G. S., \& Duthler, G. (2019). Relationship management through social media influencers: Effects of followers' awareness of paid endorsement. Public Relations Review, 45(3), 101765.

Enke, N., \& Borchers, N. S. (2019). Social media influencers in strategic communication: A conceptual framework for strategic social media influencer communication. International Journal of Strategic Communication, 13(4), 261-277.

Fickenscher, L. (2020). FTC sues to block Schick owner's \$1.4 billion merger with Harry's. New York Post. Available at https://nypost.com/2020/02/03/ftc-sues-to-block-schick-owners-1-4billion-merger-with-harrys/

Gartner (2019). Innovations in customer experience, business models and technology will transform digital commerce in the next few years. Available at:

https://www.gartner.com/smarterwithgartner/top-10-trends-in-digital-commerce/

Gaul, K., Brechbill, T., Yakel, K., Schirmer, G., Burnham, R., \& Gunderson, P. (2019). The NAA Challenge: Serving Millennials Through Subscription Boxes.

Gleason-Allured, J. (2018). What did 2018 mean for beauty? Global Cosmetic Industry Magazine.

Henderson, B. D. (1983). The anatomy of competition. Journal of Marketing, 47(2), 7-11.

Henry, Z. (2020). How Birchbox started making money? Savvy moves and a series of tough decisions. Inc. Available on https://www.inc.com/magazine/201707/zoe-henry/how-i-did-itkatia-beauchamp-birchbox.html

Hitwise (2018). Subscription boxes in 2018 US market. Available at https://hitwise.connexity.com/rs/371-PLE-119/images/Subscription-Box-Report-

2018.pdf?aliId=13641128.

Horstmeyer, T. (2020). 10 subscription box trends for 2020. Available at https://www.gravysolutions.io/post/10-subscription-box-trends-for2020\#: :text=As\%20of\%20February\%202018\%2C\%20there,type\%20of\%20subscription\%2Dba sed $\% 20$ service. 
Janzer, A. (2020). Subscription Marketing: Strategies for Nurturing Customers in a World of Churn, San Luis Obispo, CA: Cuesta Park Publishing.

Kerin, R. A. \& Hartley, S. W. (2019). Marketing: New York NY: McGraw-Hill Education.

Kneen, J. (2018, June): HelloFresh. Meal kit company tackles retail market. Marketline.

Koetsier, J. (2020). COVID-19 accelerated e-commerce growth '4-6 years.' Forbes. Available at https://www.forbes.com/sites/johnkoetsier/2020/06/12/covid-19-accelerated-e-commercegrowth-4-to-6-years/\#6879dd78600f

Kosoff, M. (2016). Why Birchbox just laid off another 12 percent of its staff. Vanity Fair. Available at https://www.vanityfair.com/news/2016/06/why-birchbox-just-laid-off-another-12percent-of-its-staff

Leavitt, Z. (2018). Macy’s moves while Birchbox stumbles. Cbinsights. Available at: https://www.cbinsights.com/research/macys-moves-while-birchbox-stumbles/

McCracken, G. (1989). Who is the celebrity endorser? Cultural foundations of the endorsement process. Journal of Consumer Research, 16(3), 310-321.

Nastasoiu, A., \& Vandenbosch, M. (2019). Competing with loyalty: How to design successful customer loyalty reward programs. Business Horizons, 62(2), 207-214.

Nielsen (2017). Getting to know today's meal kit shoppers. Available at https://www.nielsen.com/us/en/insights/article/2017/getting-to-know-todays-meal-kit-shoppers/

Noorda, R. (2019). The Element of Surprise: A Study of Children's Book Subscription Boxes in the USA. Publishing Research Quarterly, 35(2), 223-235.

Panko, R. (2019). Subscription box services statistics: The most subscribed-to brands. Available at https://clutch.co/logistics/resources/subscription-box-service-statistics.

Petro, G. (2019, April 12). Why subscription boxes are here to stay. Forbes. Available at: https://www.forbes.com/sites/gregpetro/2019/04/12/why-subscription-boxes-are-here-to-stay/

Pew Research Center (2019). Defining Generations: Where Millennials end and Generation Z begins. Available at https://www.pewresearch.org/fact-tank/2019/01/17/where-millennials-endand-generation-z-begins/

Ramasamy, A. (2018, May 28). What is the future of global subscription in the e-commerce industry? Entrepreneur. Available at https://www.entrepreneur.com/article/313813

Randall, C., Lewis, A., \& Davis, A. (2016). How subscriptions are creating winners and losers in retail. Harvard Business Review, 1-6. Available at https://hbr.org/2016/01/how-subscriptionsare-creating-winners-and-losers-in-retail

Robert, Y. (2020, October 15). Pet owners are turning to subscription services-Here's why. Available at https://www.forbes.com/sites/yolarobert1/2020/10/15/pet-owners-are-turning-to$\underline{\text { subscription-services-heres-why/?sh=1d142a5d14c9 }}$ 
Robischon, N. (2015, November 11). How Birchbox discovered the beauty consumer everyone else was ignoring. Fast Company. Available at https://www.fastcompany.com/3053388/howbirchbox-discovered-the-beauty-consumer-everyone-el

Rosa, J. A., \& Porac, J. F. (2002). Categorization bases and their influence on product category knowledge structures. Psychology \& Marketing, 19(6), 503-531.

Rudolph, T., Bischof, S. F., Böttger, T., \& Weiler, N. (2017). Disruption at the door: A taxonomy on subscription models in retailing. Marketing Review St. Gallen, (5), 18-25.

Saltzman, S. (2020). As the pandemic rattles the global economy, this beauty company's sales are booming. Available at https://fashionista.com/2020/08/madison-reed-founder-amy-errettinterview-business-coronavirus

Saint Clair, J. K., Hamilton, M. L., Woodham, O. P., Namin, A., \& Bennett, D. H. (2019). Is it Expensive? The Dual Effect of Construal Level on Price Judgments. Journal of Marketing Theory and Practice, 27(3), 298-311.

Sarabyn, K. (2017). Birchbox, and why even the best products still fail. The Startup. Available at https://medium.com/swlh/birchbox-and-why-even-the-best-products-still-fail-1b8f5de18b8d

Savary, J., \& Dhar, R. (2020). The uncertain self: How self-concept structure affects subscription choice. Journal of Consumer Research, 46(5), 887-903.

Seetharaman, P. (2020). Business models shifts: Impact of Covid-19. International Journal of Information Management, 54, 102173.

Segran, E. (2018, May 4). Here's why nobody wants to buy Birchbox, even after VCs spent $\$ 90 M$. Fast Company. Available at https://www.fastcompany.com/40567670/heres-whynobody-wants-to-buy-birchbox-even-after-vcs-spent-90m

Simeon, A. (2020, April 13). Sephora is ending its Play subscription box-\& launching a new program. Refinery29. Available at https://www.refinery29.com/en-us/2020/04/9683234/sephoracancels-play-subscription-box

Sivathanu, B. (2018). Adoption of online subscription beauty boxes: A Behavioural Reasoning Theory (BRT) perspective. Journal of Electronic Commerce in Organizations (JECO), 16(4), $19-40$.

Statista (2017). Beauty Boxes in the United States (Statista Survey). Available at https://www.statista.com/study/46452/beauty-boxes-in-the-united-states-statista-survey/

Statista (2019). Online meal kit delivery services in the U.S. Available at https://www.statista.com/study/41244/online-meal-kit-delivery-services-in-the-us-statista$\underline{\text { dossier/ }}$ 
Statista (2020). Pet market sales in the United States from 2011 to 2020, by category. Available at https://www.statista.com/statistics/253983/pet-market-sales-in-the-us-by-category/

Subscription Trade Association (2019). 2019 State of the subscription commerce economy annual report. Available at https://subta.com/wpcontent/uploads/2019/10/2019 SUBTA Annual Report.pdf

The Paypers (2019). Subscription economy landscape: mergers and acquisitions, investments, developments, Available at https://thepaypers.com/expert-opinion/subscription-economylandscape-mergers-and-acquisitions-investments-developments--779118.

Torres, J. (2019). Sephora vs. Birchbox: Winning through Digital Retaliation. Available at https://digital.hbs.edu/platform-digit/submission/sephora-vs-birchbox-winning-through-digitalretaliation/

Viswanathan, M., \& Childers, T. L. (1999). Understanding how product attributes influence product categorization: development and validation of fuzzy set-based measures of gradedness in product categories. Journal of Marketing Research, 36(1), 75-94.

Webb, V. (2018). Greek Life: Founders \& Pearls Custom Sorority Boxes Have the Swag You Want. Available at https://theglowup.theroot.com/greek-life-founders-and-pearls-customsorority-boxes-h-1821741321

Weismann, C. G. (2020). Birchbox's latest sweeping layoffs show early digital brands struggling to survive. ModernRetail. Available at https://www.modernretail.co/retailers/birchboxs-latestsweeping-layoffs-show-early-digital-brands-struggling-to-survive/

Woo, H., \& Ramkumar, B. (2018). Who seeks a surprise box? Predictors of consumers' use of fashion and beauty subscription-based online services (SOS). Journal of Retailing and Consumer Services, 41, 121-130.

YPulse (2017). How Birchbox is powering sales through social media: Insights form Millennial 20/20. https://www.ypulse.com/article/2017/05/22/how-birchbox-is-powering-sales-throughsocial-media-insights-from-millennia/ 
Table 1

\section{Major categories of SBS}

\begin{tabular}{|c|c|c|c|c|c|c|c|c|}
\hline & Beauty & Personal Care & Meal Kits & Food \& Beverage & Apparel & Kids & Pet Supplies & Miscellaneous* \\
\hline Target & $\begin{array}{l}\text { Millennial women } \\
\text { who like new } \\
\text { products and brands, } \\
\text { men } \\
\text { (gift-giving) }\end{array}$ & $\begin{array}{l}\text { Both men and } \\
\text { women }\end{array}$ & $\begin{array}{l}\text { Families, and single } \\
\text { professionals } \\
\text { seeking quick and } \\
\text { healthy meal } \\
\text { solutions }\end{array}$ & $\begin{array}{l}\text { Pleasure seekers, } \\
\text { wine and beer } \\
\text { connoisseurs and } \\
\text { foodies }\end{array}$ & $\begin{array}{l}\text { Working } \\
\text { professionals and } \\
\text { fashionistas (women } \\
\text { and men) }\end{array}$ & $\begin{array}{l}\text { Parents and } \\
\text { grandparents } \\
\text { seeking unique } \\
\text { experiences for their } \\
\text { kids and grandkids }\end{array}$ & $\begin{array}{l}\text { Pet owners, } \\
\text { especially dual- } \\
\text { income families } \\
\text { without kids }\end{array}$ & $\begin{array}{l}\text { Niche categories of } \\
\text { consumers including } \\
\text { avid book readers } \\
\text { and cigar } \\
\text { aficionados }\end{array}$ \\
\hline $\begin{array}{l}\text { Subscription boxes } \\
\text { examples }\end{array}$ & $\begin{array}{l}\text {-Birchbox } \\
\text {-Ipsy } \\
\text {-Sephora } \\
\text { Favorites } \\
\text {-Allure } \\
\text {-Macy's Beauty Box } \\
\text {-Walmart Beauty } \\
\text { Box } \\
\text {-BoxyCharm } \\
\text {-FabFitFun }\end{array}$ & $\begin{array}{l}\text {-Dollar Shave Club } \\
\text {-Billie } \\
\text {-Harry’s } \\
\text {-TheraBox } \\
\text {-Sweet Escape } \\
\text {-MindWander } \\
\text {-HopeBox } \\
\text {-Honest Box } \\
\text {-Lavish Bath Box } \\
\text {-Blume } \\
\text {-Quip } \\
\text {-Boka } \\
\text {-Prose } \\
\text {-Madison Reed } \\
\text {-eSalon } \\
\text {-Color\&Co by } \\
\text { L'Oreal } \\
\text {-Beard Club }\end{array}$ & $\begin{array}{l}\text {-Blue Apron } \\
\text {-Home Chef } \\
\text {-Hello Fresh } \\
\text {-Plated } \\
\text {-Sun Basket } \\
\text {-Daily Harvest } \\
\text {-Green Chef } \\
\text {-Martha \& Marley } \\
\text { Spoon } \\
\text {-EveryPlate } \\
\text {-Veestro } \\
\text {-Dinnerly } \\
\text {-Purple Carrot } \\
\text {-Freshly } \\
\text {-Gobble } \\
\text {-Butcher's Box }\end{array}$ & $\begin{array}{l}\text {-Wine of the month } \\
\text { club } \\
\text {-Tasting room } \\
\text {-Beer Across } \\
\text { America } \\
\text {-Craft Beer Club } \\
\text {-Brothers Coffee } \\
\text { Company } \\
\text {-Blue Bottle Coffee } \\
\text {-Bean Box } \\
\text {-Tea of the Month } \\
\text { Club } \\
\text {-Graze } \\
\text {-Misfits Market } \\
\text {-Wild Alaskan } \\
\text { Company }\end{array}$ & $\begin{array}{l}\text {-Stitch Fix } \\
\text {-Fabletics } \\
\text {-Amazon Prime } \\
\text { Wardrobe } \\
\text {-Infinite Style by } \\
\text { Ann Taylor } \\
\text {-Trunk Club, a } \\
\text { Nordstrom } \\
\text { Company } \\
\text {-Le Tote } \\
\text {-Yoga Club } \\
\text {-Dia \& Co. } \\
\text {-MeUndies } \\
\text { - ThreadBeast } \\
\text {-Watch Gang } \\
\text {-Stance } \\
\text {-The Tie Bar } \\
\text { - Menlo Club } \\
\text { - Sprezzabox } \\
\text {-Mandala } \\
\text { (ScrubScription) }\end{array}$ & $\begin{array}{l}\text {-KiwiCo } \\
\text {-Little Passports } \\
\text {-Mel Science Kit } \\
\text {-Kids Book } \\
\text {-Creation Crate } \\
\text {-Owl Crate Jr } \\
\text {-Amazon STEM } \\
\text { Toy Club } \\
\text {-Amazon Prime } \\
\text { Book Box } \\
\text { - Girls Can Create } \\
\text {-Kidpik } \\
\text {-Little Feminist } \\
\text { Book Club } \\
\text {-Stitch Fix kids }\end{array}$ & $\begin{array}{l}\text {-PetBox } \\
\text {-Bark Box } \\
\text {-PupBox } \\
\text {-Super Chewer } \\
\text {-The Dapper Dog } \\
\text { Box } \\
\text {-Cat Lady Box } \\
\text {-Meowbox } \\
\text {-WhiskerBox }\end{array}$ & $\begin{array}{l}\text {-Book Case Club } \\
\text {-Case Club } \\
\text {-Loot Crate } \\
\text {-Super Geek Box } \\
\text {-Premium Cigar } \\
\text { Club } \\
\text {-Cigar of the Month } \\
\text { Club }\end{array}$ \\
\hline Stage of the PLC & Maturity & Maturity & Growth & Growth & Growth & Growth & Growth & Intro-Maturity \\
\hline Trends & $\begin{array}{l}\text { Differentiation of } \\
\text { brands }\end{array}$ & $\begin{array}{l}\text { Personalization and } \\
\text { flexibility in } \\
\text { delivery schedules }\end{array}$ & $\begin{array}{l}\text { Most popular with } \\
\text { millennial males and } \\
\text { families with kids }\end{array}$ & $\begin{array}{l}\text { Focus on artisan } \\
\text { products, organic } \\
\text { ingredients }\end{array}$ & $\begin{array}{l}\text { Flat purchase fees } \\
\text { replaced by clothing } \\
\text { rental offerings and } \\
\text { fees and non- } \\
\text { subscription options }\end{array}$ & $\begin{array}{l}\text { Educational toys and } \\
\text { segmentation by age } \\
\text { and interest }\end{array}$ & $\begin{array}{l}\text { The introduction of } \\
\text { pet care and } \\
\text { grooming }\end{array}$ & $\begin{array}{l}\text { Focus on curation of } \\
\text { premium products }\end{array}$ \\
\hline
\end{tabular}

*While we attempted to overview the major categories of subscription boxes; however, given the number of subscription box offerings in the marketplace, our list may not be exhaustive. To this end, we have included the category of "Miscellaneous Boxes" to capture smaller subscription categories such as books and cigars among others. 
Table 2: Typology of Subscription Boxes Based on Consumer Benefits

\begin{tabular}{|c|c|c|c|}
\hline $\begin{array}{l}\text { Consumer } \\
\text { Benefit }\end{array}$ & Description & Sources & $\begin{array}{l}\text { Category } \\
\text { Relevance }\end{array}$ \\
\hline Replenishment & $\begin{array}{l}\text { Offers the convenience of replacing items on a } \\
\text { regular basis. }\end{array}$ & $\begin{array}{l}\text { Bischof, Boettger, \& Rudolph (2020) } \\
\text { Chen et al. (2018) } \\
\text { Randall, Lewis, \& Davis (2016) } \\
\text { Rudolph et al. (2017) }\end{array}$ & $\begin{array}{l}\text { Beauty } \\
\text { Personal Care } \\
\text { Food and Beverage } \\
\text { Pet Supplies }\end{array}$ \\
\hline Curation & $\begin{array}{l}\text { Offers new items within a specific niche product } \\
\text { category. }\end{array}$ & $\begin{array}{l}\text { Bischof, Boettger, \& Rudolph (2020) } \\
\text { Chen et al. (2018) } \\
\text { Randall, Lewis, \& Davis (2016) } \\
\text { Rudolph et al. (2017) } \\
\text { Sivathanu (2018) }\end{array}$ & $\begin{array}{l}\text { Beauty } \\
\text { Personal Care } \\
\text { Meal Kits } \\
\text { Food and Beverage } \\
\text { Apparel } \\
\text { Kids } \\
\text { Pet Supplies }\end{array}$ \\
\hline Access & Offers VIP or exclusive access to items. & $\begin{array}{l}\text { Chen et al. (2018) } \\
\text { Bischof, Boettger, \& Rudolph (2020) }\end{array}$ & $\begin{array}{l}\text { Beauty } \\
\text { Personal Care } \\
\text { Food and Beverage } \\
\text { Apparel } \\
\text { Kids }\end{array}$ \\
\hline Surprise & $\begin{array}{l}\text { Offers consumers an element of excitement because } \\
\text { they do not know in advance what is included in the } \\
\text { box. The contents remain a surprise until the box is } \\
\text { delivered and opened. }\end{array}$ & $\begin{array}{l}\text { Bischof, Boettger, \& Rudolph (2020) } \\
\text { Chen et al. (2018) } \\
\text { Noorda (2019) } \\
\text { Petro (2019) } \\
\text { Rudolph et al. (2017) } \\
\text { Sivathanu (2018) } \\
\text { Woo \& Ramkumar (2018) }\end{array}$ & $\begin{array}{l}\text { Beauty } \\
\text { Personal Care } \\
\text { Meal Kits } \\
\text { Food and Beverage } \\
\text { Apparel } \\
\text { Kids }\end{array}$ \\
\hline
\end{tabular}




\begin{tabular}{|c|c|c|c|}
\hline Affiliation & $\begin{array}{l}\text { Offers items associated with a specific group identity } \\
\text { such as a sorority or fraternity. }\end{array}$ & $\begin{array}{l}\text { Cracknell (2017) } \\
\text { Gaul et al. (2019) } \\
\text { Webb (2018) }\end{array}$ & Apparel \\
\hline
\end{tabular}


Figure 1: The Four C's of SBS

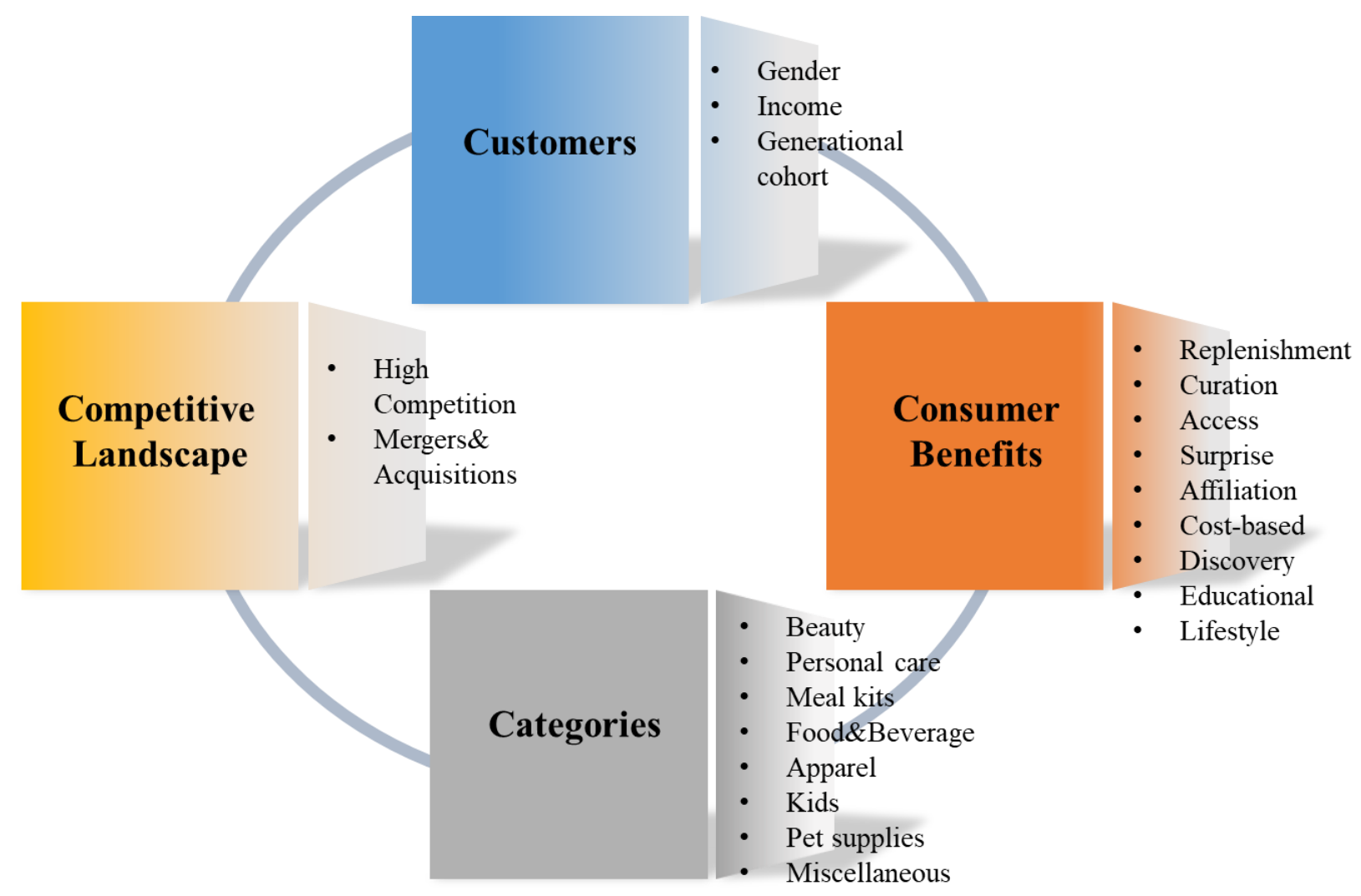




\section{Figure 2: Five Tenets for Successfully Managing SBS}

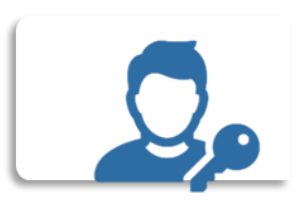

\section{Leverage social media influencers}

- Borrow brand equity from social media influencers to promote subscription services.

- Create opportunities for personalized encounters between subscribers and social media influencers to build brand experiences.

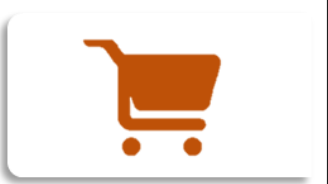

\section{Offer bricks and clicks}

- Partner with retail outlets to increase trial and awareness.

- Leverage brick-and-mortar outlets as a form of distribution. Offer "order online, pick-up" in store option and a site to return perishable goods.

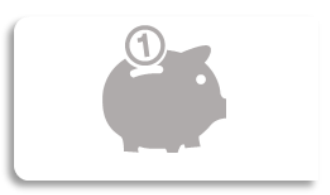

\section{Reward customers for staying}

- Provide customized and desirable reward programs to drive retention.

- Provide subscribers with the ability to pause a subscription and continue later.

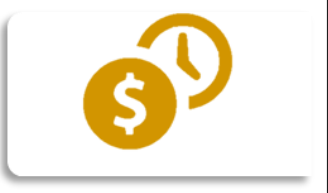

\section{Increase perceptions of convenience}

- Highlight the different aspects of convenience subscriptions offer using compelling storybased messaging that focuses on the time, effort, decision, and transaction-based benefits enjoyed by actual users.

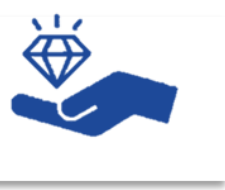

\section{Increase perceptions of value}

- Provide consumers with opportunities for box customization.

- Differentiate from current offerings by providing unique offerings or early releases not found in other channels. 